\title{
Hepatitis C Virus (HCV) infection in general population of District Bannu Khyber Pakhtunkhwa, Pakistan
}

\author{
Naveed Jan ${ }^{1}$,Zia Ur Rahman Awan ${ }^{1 *}$ and Mehboob Ur Rahman \\ Awan ${ }^{2}$ \\ 1. Department of Zoology, Govt. Post-Graduate College Bannu-Pakistan \\ 2. MTI, District Head Quarter Teaching Hospital, Bannu-Pakistan \\ *Corresponding author's email: ziabiotech78@yahoo.com
}

Citation

Naveed Jan, Zia Ur Rahman Awan and Mehboob Ur Rahman Awan. Hepatitis C Virus (HCV) infection in general population of District Bannu Khyber Pakhtunkhwa, Pakistan. Pure and Applied Biology. Vol. 9, Issue 3, pp1679-1689. http://dx.doi.org/10.19045/bspab.2020.90178

\begin{tabular}{llll}
\hline \hline Received: 01/01/2020 & Revised: 22/03/2020 & Accepted: 31/03/2020 & Online First: 08/04/2020 \\
\hline \hline
\end{tabular}

\section{Abstract}

Hepatitis $\mathrm{C}$ is one of the much common liver diseases all over the world. It is caused by hepatitis $\mathrm{C}$ virus (HCV) and a significant number of patient's proceed in the direction of chronic hepatitis, hepatocellular carcinoma and liver cancer. Globally it is assumed that more than 250 million people are affected from HCV. Moreover 10 million persons in Pakistan are infected from HCV. The current study was conducted with main aim to investigate the rate of infection in general population of District Bannu, Khyber Pakhtunkhwa, Pakistan. A total of 1016 individuals (including 611 males and 405 females) of the age group 1 to 75 years were collected. All the individuals were screened for anti-HCV antibodies with Immunochromatographic (ICT) test. The results shows that of the total 1016 samples, 45 (4.4\%) were found positive for anti-HCV antibodies while $971(95.5 \%)$ were found negative for anti-HCV antibodies. The infection was more prevalent in the age group of 46-60 years $(9.7 \%)$ peoples and lower in the age group of 1 to 15 years $(2.1 \%)$. The major risk factors were dental surgery, piercing of nose and ears, skin tattooing, blood transfusion, reuse of contaminated blades, reuse of syringes, general surgery, interfamilial prevalence and drug abuse. Hepatitis $\mathrm{C}$ is still endemic in the general population of District Bannu and needs proper screening and preventive measurements to control the disease.

Keywords: Bannu; Endemic; HCV infection; Prevalence; Risk factors

\section{Introduction}

The word Hepatitis is Latin phrase that means 'inflammation of liver'. Now a day's the viral hepatitis is the leading health issue throughout the world [1]. Hepatitis $\mathrm{C}$ is almost familiar liver diseases all over the global. It is cause due to hepatitis $\mathrm{C}$ virus (HCV) and consequential amount of patient does proceed in the direction of chronic hepatitis, hepatocellular carcinoma and liver cancer [2].
There are two periods of $\mathrm{HCV}$, acute and chronic. Acute concern's to the $\mathrm{HCV}$ contagion that is for the first six months. During in initial infection it is estimated that $70 \%$ to $80 \%$ of the patient have no symptoms (asymptomatic). Approximately $20 \%$ to $30 \%$ patients by acute $\mathrm{HCV}$ infection can elaborate symptoms. The symptoms incorporate discomfort, deficiency, anorexia, and jaundice. The RNA of hepatitis $C$ can be known in the serum within 1 to 2 weeks after infection. 
The HCV contamination which lasts more than six months develops chronic. A considerable percentage of hepatitis C contaminated peoples, nearby $75 \%$ to $85 \%$ progress towords chronic $\mathrm{HCV}$ infection which causes liver failing, liver cirrhosis, hepatocellular carcinoma (HCC), liver fibrosis, and $\mathrm{HCV}$ related extra-hepatic complication [3].

First of all Choo and coworkers of Chiron Co-operation Group in 1991 discovered the complete genome of $\mathrm{HCV}$. Hepatitis C virus (HCV) is a sole member of the genus Hepacivirus, in the family Flaviviridae. The $\mathrm{HCV}$ is a single stranded RNA virus having $96 \mathrm{~kb}$ length. The single strand of RNA are encodes by a large polyprotein of about 3000 amino acid. On the bases of geographical distribution, prevalence, and transmission $\mathrm{HCV}$ is divided by 11 genotypes and extra than 100 subtypes represented as a, b, c etc. Hepatitis $\mathrm{C}$ virus (HCV) is the serious health issue throughout the world and it is accountable for the second almost familiar cause of viral hepatitis. Hepatitis $C$ virus is noted twain to be hepatotropic and lymphotropic virus [4]. Now a day's the primary route of transmission of $\mathrm{HCV}$ is extreme treat of injection and repeat of unsterilized needles [5]. For this purpose health care workers perform significant job in effective transmission of HCV. Usually the health preserve workman's perform exercise on unreliable and unsterilized syringes. The most of health preserve workman's are never trained scientifically or therapeutically capable and have no idea about the common sterilization techniques [6]. Blood transfusion and organ transplantation also acts as a barrier to transfer the HCV. This is due to resources limitation, poorly trained staff, inadequate testing donor's blood to detect the antibody, weak infrastructure etc. Another important component for transmission of hepatitis $\mathrm{C}$ is shaving at barber shops. Because majority of the barber use unsterilized razors at their shop and there is a possibility that it may be contaminated. Intravenous drug and homosexuality acts as leading risk components to transfer hepatitis C. Beside this the further routs that is responsible to transfer the HCV are dental and surgical procedures, from mother to child, shared personal items, circumcision, tattooing, and ear piercing [7].

Day by day the death counts caused by hepatitis $\mathrm{C}$ in the world are increases. Centers for Disease Control and Prevention (CDC) reported that the death counts in the U.S are increases from 11,051 in 2003 to 19,368 in 2013. These researchers correlated the counts of people of United States as died per year of HCV with the counts of people pass away due to 60 diverse infectious. These 60 sicknesses involve Human immune deficiency virus infections, pneumonia disease, tuberculosis, measles, mumps, mad dog disease, Lyme disease etc. Now researchers found that there is 6 percent increase annually in the deaths due to hepatitis $\mathrm{C}$. During the same period, the researchers found that the deaths from the other 60 diseases are continuous decreases. The number of deaths down from 24,745 in 2003 to 17,915 in 2013 means that 3 percent decreases per year. According to recent prediction around 250 million individuals are affected from hepatitis $\mathrm{C}$ worldwide. It is assumed that more than 250 lac peoples are dies in one year from hepatitis $\mathrm{C}$ virus infection. The HCV frequency in hemodialysis patients in highly advance countries are from $8 \%$ to $20 \%$ and much more in those countries which are less developed. Europe contains 2 to 5 million $\mathrm{HCV}$ positive persons. In Saudi Arabia in 2001 anti HCV prevalence in dialysis patient was $43.9 \%$. Improving nations like Pakistan the HCV infection is the big problem of health and quickly emerging infection disease [8].

Pakistan is the $6^{\text {th }}$ bulk populous nation of the global in respect to population. Prevalence of HCV infection in Pakistan is ranges from 2.2 to $14 \%$. It is reported that approximately 1 crore individuals in Pakistan get infection with hepatitis C. In 
Pakistan the prevalence is different in the various provinces; prevalence observed in Punjab is $6.7 \%$, Sindh 5\%, Baluchistan $1.5 \%$, and in Khyber Pakhtunkhwa it is $1.1 \%$. In Pakistan it's noted that the high use of needles are the big route of transmission of $\mathrm{HCV}$. Other hazards element that is responsible to transfer the $\mathrm{HCV}$ in Pakistan is sex workers, injection drug user, and household contacts. Also in Pakistan most of the people shave at hair cutter shop. Barbers use the same blade for many people, possibly contaminated and it is the major route of transmission [9].

According to recent research the highest $\mathrm{HCV}$ prevalence is noted from Lahore which is $13.5 \%$ or $14 \%$ then Jasmshoro which is $9 \%$ and then Mardan which is $9 \%$. Pakistan is the growing nation. Most of the individuals are illiterate that results the knowledge about pathogenicity, spreading routes, suitable procedure of detection and medicine is rare. That's why the exposure numbers of hepatitis $\mathrm{C}$ is increase day by day in Pakistan particularly in Khyber Pakhtunkhwa [10].

In KPK resources to screen the blood is limited. The contaminated blood transfusions are the major route to spread hepatitis $\mathrm{C}$ in thalassemic patients. Major surgery is also an important route of transmission of HCV. In KPK, majority of the nursing home have no proper apparatus to screen the blood and people have no idea above the transmission of HCV. Dental surgery, intravenous drug users, and dialysis are also the most important factors in KPK for the transmission of HCV [11]. In Bannu hepatitis $\mathrm{C}$ efficacy is increasing day by day. According to recent research the possible ways for the transmission of $\mathrm{HCV}$ is multiple therapeutic injection received (35.4\%), dental procedures (20\%), blood transfusion (6.4\%), shaving by barber (36.4\%), and tattooing (1.8\%). Genotype $3 \mathrm{a}$ and genotype $3 \mathrm{~b}$ are mostly transmitted by contaminated blades of shear, contaminated needles, and contaminated dental equipment's while genotype $2 \mathrm{a}$ and $1 \mathrm{a}$ are only transmitted through dental procedures [12]. In view of the about facts the present work was conducted with the aims to investigate rate of infection of $\mathrm{HCV}$ and to observe the various risk factors responsible for the transmission of $\mathrm{HCV}$ in general population of district Bannu.

\section{Materials and methods Study design}

The study was conducted in general population of district Bannu, KPK, Pakistan. The population of district Bannu is near to one million which are dispersing around a region of 1,227 square kilometers. Majority of the population are live in villages. The average annual growth rate of district Bannu is approximately $3 \%$.

\section{Samples collection}

A total of 1016 blood specimen were collected from peoples having fitness issues like fever, malaise, heart burdening, gloomy feces, fatigue, joint pain, jaundice, nausea, dark yellow eyes, anorexia, abdominal pain etc. As all the problems are related at some extent to liver contamination, and then a consent was filled up from these individuals having information like name, sex, age, marital status, education, occupation, address, previous record, sign and symptoms and analytical tests. The study was evaluated and approved by Ethical committee of the institution.

A $3 \mathrm{ml}$ of blood specimen was collected through sterile syringe from each individual. The blood was transferred to plain container and allowed to clot for separation. The blood was spun at $3000 \mathrm{rpm}$ for 7 to 8 minute in centrifuge, and serum was isolated into a sterilized plain container(s) and then stored at -20 degree centigrade before use in Laboratory of District Headquarter Hospital (DHQ) Bannu. The serum was diagnose for anti$\mathrm{HCV}$ anti bodies through Immunochromatographic Tests (accurate diagnostic USA) according to manufacturer's instructions. 


\section{Statistical analysis}

The data was analyzed by using Microsoft office Excel and the results were expressed in percentages.

\section{Results}

Total 1016 blood specimen were collected from the peoples of 1 to 75 years age from district Bannu Pakistan. Out of the total 1016 individuals, 611 were males and 405 were female. The blood specimens were then screened to detect the antibodies which are produce against $\mathrm{HCV}$ antigen through Immunochromatographic (ICT) test. The results shows that out of the total 1016 samples, $45(4.4 \%)$ were found positive (antibodies are detected against HCV antigen), while 971 (95.5\%) were found negative (antibodies against HCV antigen were not detected).

Sex-wise prevalence of $\mathrm{HCV}$ infection in District Bannu

During the current research work genderwise prevalence of $\mathrm{HCV}$ infection in District Bannu was demonstrated. Out of the total 45 ICT positive individuals 29 $(2.8 \%)$ were male and $16(1.5 \%)$ were females. This shows that prevalence of $\mathrm{HCV}$ infection with respect to sex-wise is more in males as compare to females (Fig. $1)$.

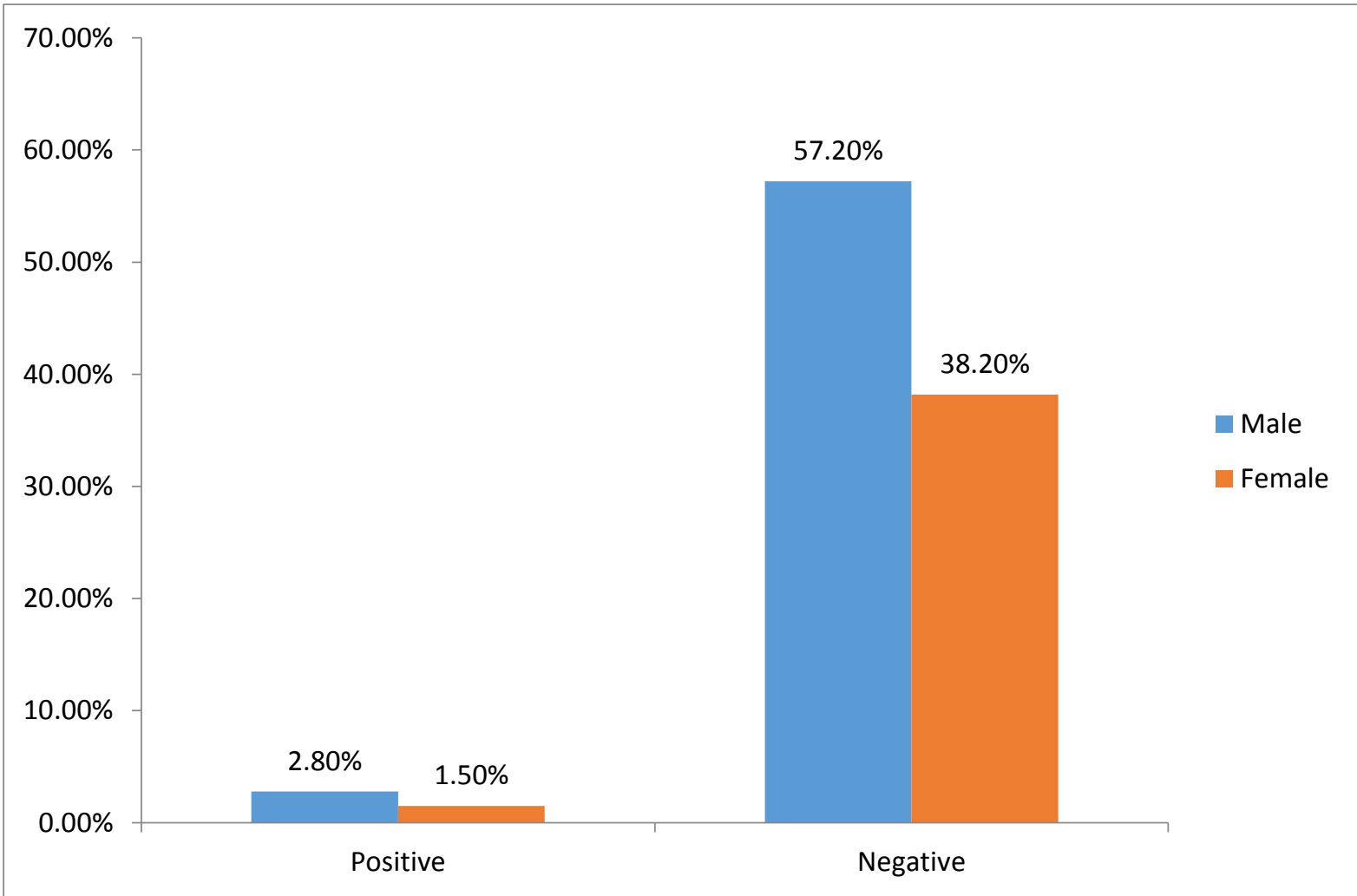

Figure 1. Sex-wise prevalence of HCV infection in District Bannu

Area-wise prevalence of $\mathrm{HCV}$ infection in District Bannu

During the current research work area-wise prevalence of $\mathrm{HCV}$ infection in District Bannu was demonstrated. Out of the total 45 ICT positive individuals 33 (3.2\%) belongs to rural areas while $12(1.1 \%)$ belongs to urban areas or main city. This demonstrated that hepatitis $\mathrm{C}$ is prevalent in in rural areas as compare to the urban areas (Fig. 2). 


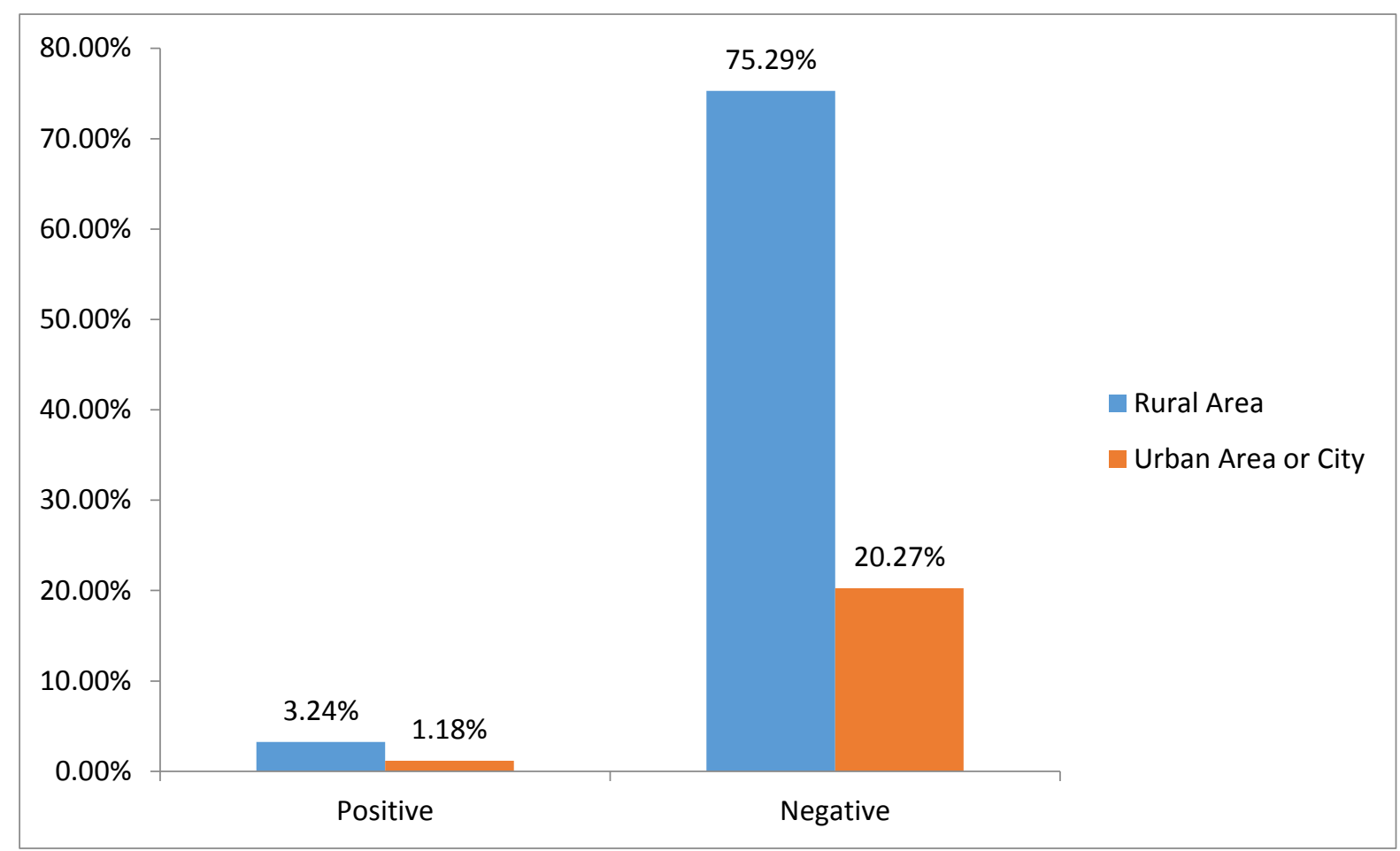

Figure 2. Area-wise prevalence of $\mathrm{HCV}$ infection in District Bannu

Age-wise distribution of hepatitis C infection in District Bannu

The individuals of age 1 to 75 years were divided into five groups. The $\mathrm{HCV}$ infection was determined to be more in the age groups of $46-60$ years $(9.7 \%)$ and reduced in the age period of 1 to 15 years $(2.1 \%)$. In the age period of 16 to 30 years it was $3.4 \%$ and in the age group of 31 to 45 it was $4.4 \%$ (Fig. 3 ).

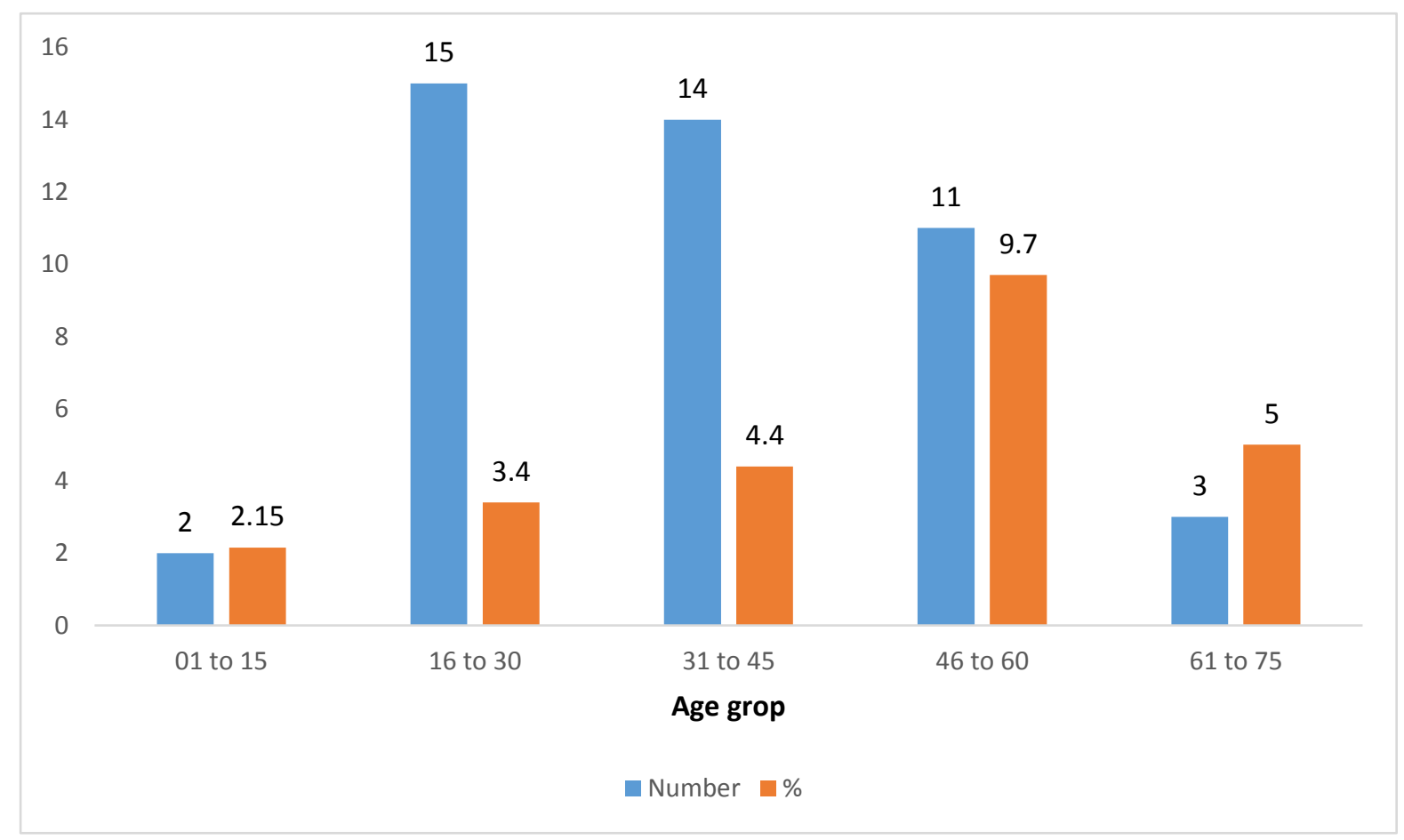

Figure 3. Age-wise distribution of hepatitis $\mathrm{C}$ infection in District Bannu 


\section{$\mathrm{HCV}$ prevalence in respect to different risk factors in District Bannu}

The various types of risk factors through which HCV infection can be transmitted in District Bannu were also determined in this work. The highest risk agent in District Bannu is dental surgery (51.1\%). The other risk agents were body piercing and tattooing $(42.2 \%)$, reuse of contaminated blades $(17.4 \%)$, reuse of syringes $(13.3 \%)$, drug addiction $(6.6 \%)$, blood transfusion $(37.7 \%)$, intrafamilial prevalence each $(11.1 \%)$, and general surgery $(11.1 \%)$ (Fig. 4).

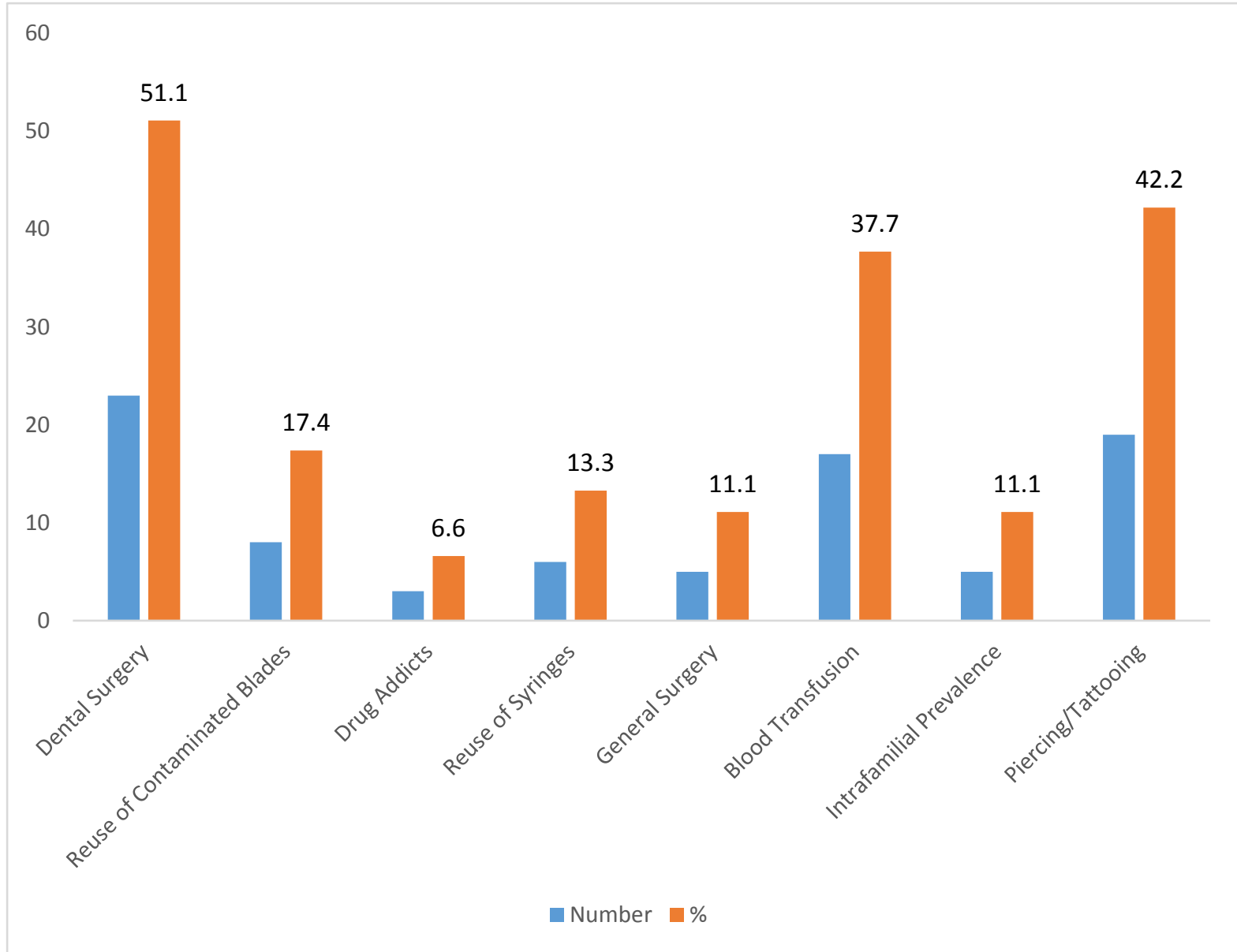

Figure 4. HCV prevalence in respect to different risk factors in District Bannu

HCV prevalence in respect to marital status in District Bannu

During the current research work $\mathrm{HCV}$ prevalence in respect to marital status in District Bannu was also investigated. Among the total 45 ICT positive individuals $34(75.5 \%)$ were married and 11 (24.4\%) were unmarried. This demonstrates that hepatitis $\mathrm{C}$ prevalence is more in married people then unmarried in District Bannu (Fig. 5). 


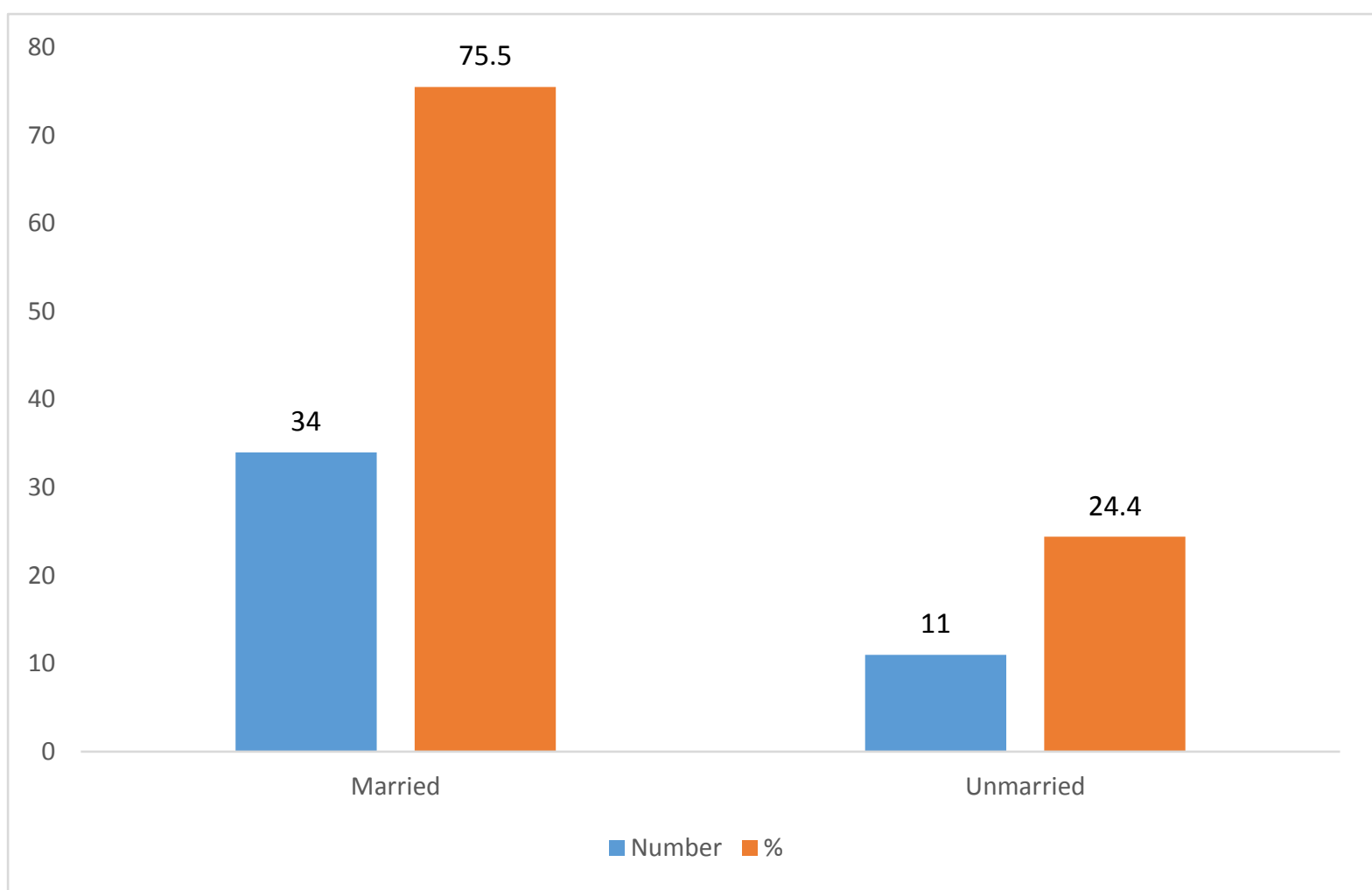

\section{Figure 5. HCV prevalence in respect to marital status in District Bannu}

\section{Discussion}

Hepatitis C virus (HCV) infection is a chief fitness issue in growing territory including Pakistan. Approximately 0.2 billion (20 crore) individuals are affected from HCV which is nearly $3.3 \%$ of the global population [13]. HCV is a primary issue of chronic liver disorder counting chronic hepatitis, hepatocellular carcinoma, liver cancer, and end stage liver disease. WHO assumed in 2004 that per year the counts of deaths caused by hepatic cancer and liver inflammation were 308,000 and 785,000. In Pakistan the prevalence of $\mathrm{HCV}$ infection is $5 \%$ [14].

First of all HCV was revealed by Choo and co-companion in 1989 as the major causative agent of non-A, non-B hepatitis. In growing nations the counts of affected peoples are higher correlated to the advanced nations because of lacking of proper equipment's [11]. The earliest infection of HCV was identified in 1992 in Pakistan. According to the recent research approximately 1 corer individuals of Pakistan carries HCV which is nearly $6 \%$, of the total population of 140 million peoples. Now from this information it is clear that HCV is epidemic in Pakistan due to illiteracy and lack of health instrument, and it seemly an arduous confront. The percentage of $\mathrm{HCV}$ exposure individuals of Pakistan is high as compared to the adjacent countries like Iran, India, Afghanistan, Nepal and Myanmar. The hepatitis $C$ virus (HCV) are spread in Pakistan because there is no proper learning system, people have no idea about the disease, lacking of therapeutically and carefully qualified fitness concern worker [15]. HCV is usually asymptomatic but once appeared then it develops to liver fibrosis, liver cirrhosis, liver failing, and end stage liver disease. It is reported that in 15 to $25 \%$ of affected individuals the hepatitis $\mathrm{C}$ virus acquit the host body due to their strong immune defense while the leftover 75 ;to $85 \%$ of the affected individuals by HCV progress towards chronic hepatitis which leads to liver fibrosis, and hepatocellular carcinoma [16]. According to recent research the liver cirrhosis will leads to hepatocellular carcinoma (HCC) within 10 
years and still no vaccine is available for hepatitis $C$ virus [2].

Prevalence of hepatitis $\mathrm{C}$ infection is different in Pakistan ranges from 2.2 to $14 \%$. HCV prevalence is different in the four provinces; prevalence rate observed in Punjab is $6.8 \%$, Sindh $5.3 \%$, Baluchistan $1.7 \%$, and in Khyber Pakhtunkhwa it is $1.3 \%$ [9]. It was noted that the prevalence of $\mathrm{HCV}$ infection in Islamabad is $5.31 \%$ [8]. According to recent research the maximum prevalence rate of $\mathrm{HCV}$ infection is noted from Lahore which is $13.5 \%$ then Jasmshoro which is $9 \%$ and then Mardan which is also 9\%. Pakistan is growing nation and most of the populace is illiterate. They have no idea about $\mathrm{HCV}$, its pathogenicity, its routes (risk factors), its peculiar procedure of detections and therapy. That's way the counts of infected peoples is increases day by day in Pakistan and chiefly in KP province. Now a day's hepatitis $C$ virus is one of the the massive issue of Pakistan [10].

Human Development Index reports that $\mathrm{HCV}$ is present in 134 countries out of 174 countries of the world [17]. HCV are realized that is present both in hepatic as well as in lymphatic system and is accountable that it is the second bulk usual reason of viral hepatitis [4]. Recent report shows that $\mathrm{HCV}$ infected extra populate then HBV. Annually 10 lakhs fresh HCV cases are noted world w;idely [10]. The $\mathrm{HCV}$ replicates at the rate of approximately one trillion virions/day and it is predicted that the half-life of the virus is two to three hours [3].

The current research works are accord by the reality that male denizens are highly infected by HCV with prevalence of $2.8 \%$ of District Bannu. The female denizens is lowest infected by HCV with $1.5 \%$ prevalence District Bannu. The higher prevalence of $\mathrm{HCV}$ in the male population is apparently by virtue of exposure to risk agents. In our surrounding environs, the woman's are not contacted with certain major risk agents e.g. Drug addicts, shaver shops, blood and organ donation and in jobs and business etc. All these are important to transfer the HCV.

Our study is supported by Awan et al. [13] who carried his work in IDPs of South Waziristan Agency, Pakistan and demonstrated that hepatitis $\mathrm{C}$ prevalence in males is $26 \%$ while $15 \%$ in females. The same result has been affirmed by Ali et al. [16] as demonstrated that hepatitis C prevalence in males is $4 \%$ while $2 \%$ in females. The current study is also affirmed by Ali et al. [11] who have reported that hepatitis $\mathrm{C}$ prevalence in males is $17.30 \%$ while $12.68 \%$ in females.

According to the current research works the hepatitis $\mathrm{C}$ prevalence is superior in rural areas $(3.2 \%)$ as compared to urban area or city $(1.1 \%)$ of District Bannu. Several recent research works affirmed the fact that hepatitis $\mathrm{C}$ prevalence was superior in rustic areas as compared to cities $[18,19]$. The higher prevalence of $\mathrm{HCV}$ in the rural areas is by reason of lack of knowledge, poverty and poor awareness among the peoples. Majority of the peoples of rural areas are illiterate. They don't obey the universal preventive measurements. The current study revealed that the prevalence of $\mathrm{HCV}$ is less $(2.15 \%)$ in children and postpubscent period individuals with age period of $1-15$ years. The lower hepatitis $C$ prevalence in children and postpubscent period individuals is by the reason of least exposure to several major risk agents like shaver shops, use of drugs, blood transfusion, organ transformation, and surgeries etc. Beside this they have vigorous defense system that perform crucial task to eliminate the virus from the body. The highest hepatitis $\mathrm{C}$ prevalence is observed in age period of 46-60 years which are $9.7 \%$. Its main reason is that; the individuals of this age group are in direct contact with $\mathrm{HCV}$ important risk agents like dental operations, general surgery, blood transfusion, organ transformation and with shaver shops.

The second superior prevalence of $\mathrm{HCV}$ was observed in age period of 61-75 years which is $5 \%$ and $31-45$ years which is $4.4 \%$. 
These are mainly due to their week immunity, reuse of contaminated blades and syringes, and have no idea about HCV. The moderate prevalence of $\mathrm{HCV}$ is observed in age group of 16 - 30 years which is $3.4 \%$. It is because; the individuals of this age period have fairly connection with the risk agents that transmitted the $\mathrm{HCV}$ infection. Beside this it has a strong immune power; correlated to the individuals over then 31 years.

The highest active HCV prevalence was ascertained by Awan et al. [13] in the age group 41-60 years which is $24.3 \%$. Ali et al. [16] perceived the highest hepatitis $C$ infection in the age group of 51 and above which is $7.69 \%$ and lowest in age period 10 - 20 years which is $0 \%$. Janahi et al. [20] also reported the highest hepatitis C prevalence in age period 51-60 years and lowest in age period 10-20 years.

The current research work divulges the peculiar risk factors of hepatitis $\mathrm{C}$ in District Bannu. The major risk factors perceived in the current study is dental surgery $(51.1 \%)$, piercing and tattooing $(42.2 \%)$, blood transfusion $(37.7 \%)$, reuse of contaminated blades $(17.4 \%)$, reuse of syringes $(13.3 \%)$, general surgery $(11.1 \%)$, intrafamilial prevalence $(11.1 \%)$ and drug addicts $(6.6 \%)$. Our study is affirmed by Awan et al. [13] proclaimed that the major source that is responsible for the transmission of HCV is the dental surgery. The current study is also validated by Ali et al. [11] reports that the major risk factor that transmitted the HCV is dental surgery $(14.28 \%)$.

Janjua et al. [21] rumoured that $68 \%$ of the peoples gotten injections in Digri and Mirpur khas in which nearly 54\% were newly sterilize needles. According to World Health Organization in Pakistan annually 12 to 15 lakhs blood transfusion are occurred. Luby et al. [22] proclaimed that in Karachi merely $23 \%$ blood banks screened the blood in which $29 \%$ does not reserve the blood at the essential temperature which is required. Recent report suggested that merely $13 \%$ savers shops; knows about the HCV that it cloud be convey through unsterilized blades. Now in this $11.4 \%$ were sterilize the blades with antibacterial mixture while $46 \%$ use the blade again [23]. In the current research work the association of risk agents with hepatitis $\mathrm{C}$ was also affirmed by several recent research studies [17, 24, 25].

In the present study hepatitis $\mathrm{C}$ prevalence in married patients was found higher (75.5\%) as correlated to unwed patients $(24.4 \%)$. The wedded couple quickly infected one another and smoothly transmits the HCV. The result of the current work was concord with result of Basit et al. [26] proclaimed that hepatitis $C$ prevalence is higher in married patisent. Ayele and Solomon, [27] also reported that HCV was superior in wedded patients as compare to unwedded patients. Beside this Adekeye et al. [28] also rumoured that HCV prevalence was superior in wedded patients as correlated to unwedded patients.

\section{Conclusion}

$\mathrm{HCV}$ is endemic in the general population of District Bannu due to illiteracy, lack of sterilized health instruments, lack of awareness, and shortage of scientifically trained health care workers. Proper management and HCV screening needs to control and prevent the dreadful disease in the study area.

\section{Authors' contributions}

Conceived and designed the experiments: ZUR Awan \& $\mathrm{N}$ Jan, Performed the experiments: $\mathrm{N}$ Jan, Analyzed the data: ZUR Awan, Contributed materials/ analysis/ tools: ZUR Awan \& MUR Awan, Wrote the paper: ZUR Awan.

\section{References}

1. Riaz M, Idrees M, Kanwal H \& Kabir F (2011). An overview of Triple infection with Hepatitis B, C and D viruses. Virol J 8: 368.

2. Yousaf MZ, Idrees M, Saleem Z, Rehman IU \& Ali M (2011). Expression of core antigen of $\mathrm{HCV}$ genotype $3 \mathrm{a}$ and its evaluation as screening agent for $\mathrm{HCV}$ infection in Pakistan. Virol J 8: 364. 
3. Chen SL \& Morgan TR (2006). The Natural History of Hepatitis C Virus (HCV) Infection. Inter $J$ of $\mathrm{Med} \mathrm{Sci}$ 3(2): 47-52.

4. Attaullah S, Khan S \& Ali I (2011). Hepatitis $\mathrm{C}$ virus genotypes in Pakistan: a systemic review. Virol J 8: 433.

5. Muhammad N \& Jan MA (2005). Frequency of hepatitis $\mathrm{C}$ in Buner, NWFP. $J$ of the College of Physi and Surg Pak 15: 11-4.

6. Raglow GJ, Luby SP \& Nabi N (2001). Therapeutic injections in Pakistan: from the patients perspective. Trop Med Int Health 6: 69-75.

7. Raja NS \& Janjua KA (2008). Epidemiology of hepatitis $\mathrm{C}$ virus infection in Pakistan. $J$ of Microbiol, Immunol and Infec 41: 4-8.

8. Raza S, Maqbool F, Bhatti ZA, Rehman MMU, Nadeem S, Raza A \& Murtaza N (2014). Prevalence of Hepatitis $\mathrm{C}$ infection in young adults of district Bannu. $J$ of Pharm and Biol Sci 9: 71-76.

9. Umar M \& Bilal M (2012). Hepatitis C, A Mega Menace: A Pakistani Perspective. J of Pione Med Sci 2: 6872.

10. Ahmad B, Ali S, Ali I, Azam S \& Bashir S (2012). Response rates of standard interferon therapy in chronic HCV patients of Khyber Pakhtunkhwa (KPK). Virol J 9: 18.

11. Ali I, Siddique L, Rehman LU, Khan NU, Iqbal A, Munir I, Rashid F, Khan SU, Attache S, Swati ZA \& Aslam MS (2011). Prevalence of HCV among the high risk groups in Khyber Pakhtunkhwa. Virol J 8: 296.

12. Saleha S, Kamal A, Ullah F, Khan N, Mahmood A \& Khan S (2014). Prevalence Of hepatitis C Virus Genotypes in District Bannu, Khyber Pakhtunkhwa, Pakistan. Hindawi Publ Corpor: 5.

13. Awan ZUR, Shah AH, Rahman HMU \& Khan S (2012). Hepatitis C virus infection in IDPs of war against terrorism in South Waziristan Agency, Pakistan. Global Adv Res $J$ of Biotechnol 1(2): 017-022.

14. Waheed Y, Safi SZ \& Qadri I (2011). Role of Potash Alum in Hepatitis C virus Transmission at Barbers Shop. Virol J 8: 211.

15. Khan S, Attaullah S, Ali I, Ayaz S, Naseemullah, Khan SN, Siraj S \& Khan J (2011). Rising burden of Hepatitis C Virus in hemodialysis patients. Virol J 8: 438.

16. Ali A, Ahmad H, Ali I, Khan S, Zaidi G \& Idrees M (2010). Prevalence of active hepatitis $\mathrm{C}$ virus infection in district Mansehra Pakistan. Virol J 7: 334.

17. Waheed Y, Shafi T, Shafi SZ \& Qadri I (2009). Hepatitis C virus in Pakistan: A systematic review of prevalence, genotypes and risk factors. World $J$ of Gastroenterol 15(45): 5647-5653.

18. Aziz S, Khanani R, Noorulain W \& Rajper J (2010). Frequency of Hepatitis B and hepatitis C in rural and periurban Sindh. $J$ of the Pak Med Assoc 60: 853.

19. Abbas SZ, Ali M, Muhammad AH, Shaw S \& Abbas SQ (2009). Frequency of HCV infection and its genotypes among patients attending a liver clinic and voluntary blood donors in a rural area of Pakistan. Pak J of Med Sci 25: 579-582.

20. Janahi EM, Mannai MA, Singh H \& Jahromi MM (2015). Distribution of Hepatitis C Virus Genotypes in Bahrain. $J$ of Hepat Mon 15(12): 30300.

21. Janjua NZ, Akhtar S \& Hutin YJ (2005). Injection use in two districts of Pakistan; implications for disease prevention. Inter J of Qual Health Care 17: 401-408.

22. Luby S, Khanani R, Zia M, Vellani Z, Ali M, Qureshi AH, Khan AJ, Mujeeb SA, Shah SA \& Fisher-Hoch S (2000). Evaluation of blood bank practices in Karachi, Pakistan, and the 
government's response. Health Pol Plan 15: 217-222.

23. Janjua NZ \& Nizamy MA (2004). Knowledge and practices of barbers about hepatitis $\mathrm{B}$ and $\mathrm{C}$ transmission in Rawalpindi and Islamabad. $J$ of the Pak Med Assoc 54: 116-119.

24. Sawayama Y, Hayashi J, Kakuda K, Furusyo N, Ariyama I \& Kawakami Y (2000). Hepatitis C virus infection in institutionalized psychiatric patient's possible role of transmission by razor sharing. Dig Dis Sci 45: 351-356.

25. Wazir MS, Mehmood S, Ahmed A \& Jadoon HR (2008). Awareness among barbers about health hazards associated with their profession. $J$ of Ayub Med College Abbottabad 20: 35-38.
26. Basit A, Rahim K, Ahmad I, Shafiq M, Mushtaq S, Shaheen H \& Khan I (2014). Prevalence of Hepatitis B and $\mathrm{C}$ infection in Pakistan. J of Infec and Mol Biol 2(3): 35-38.

27. Ayele AG \& Solomon GS (2013). Prevalence and Risk Factors of Hepatitis B and Hepatitis C Virus Infections among Patients with Chronic Liver Disease in Public Hospitals in Addis, Ababa, Ethiopia. Trop Med 2: 1-7.

28. Adekeye AM, Chukwuedo AA, Zhakom PN \& Yakubu RS (2013). Prevalence of Hepatitis B and C among Blood Donors in Jos South LGA, Plateau State, Nigeria. Asian J of Med Sci 5(5): 101-104. 